\title{
Titanite Mineralization of Microbial Bioalteration Textures in Jurassic Volcanic Glass, Coast Range Ophiolite, California
}

\section{OPEN ACCESS}

Edited by:

Mónica Sánchez-Román,

Vrije Universiteit Amsterdam,

Netherlands

Reviewed by:

Gerhard Franz,

Technische Universität Berlin,

Germany

Huan Cui,

Vrije Universiteit Brussel, Belgium

${ }^{*}$ Correspondence:

Matthew R. M. Izawa

matthew.izawa@gmail.com; matthew_izawa@okayama-u.ac.jp

tPresent address:

Debarati Das,

Department of Earth and Planetary Sciences, McGill University, Montreal,

QC, Canada

Specialty section: This article was submitted to Biogeoscience,

a section of the journal

Frontiers in Earth Science

Received: 20 June 2018 Accepted: 11 November 2019

Published: 03 December 2019

Citation:

Izawa MRM, Banerjee NR,

Shervais JW, Flemming RL, Hetherington CJ, Muehlenbachs K,

Schultz C, Das D and Hanan BB

(2019) Titanite Mineralization of Microbial Bioalteration Textures in Jurassic Volcanic Glass, Coast

Range Ophiolite, California.

Front. Earth Sci. 7:315.

doi: 10.3389/feart.2019.00315
Matthew R. M. Izawa ${ }^{1,2 *}$, Neil R. Banerjee ${ }^{2}$, John W. Shervais ${ }^{3}$, Roberta L. Flemming ${ }^{2}$, Callum J. Hetherington ${ }^{4}$, Karlis Muehlenbachs ${ }^{5}$, Cynthia Schultz ${ }^{6}$, Debarati Das ${ }^{1+}$ and Barry B. Hanan ${ }^{7}$

\footnotetext{
${ }^{1}$ Institute for Planetary Materials, Okayama University, Misasa, Japan, ${ }^{2}$ Department of Earth Sciences, University of Western Ontario, London, ON, Canada, ${ }^{3}$ Department of Geology, Utah State University, Logan, UT, United States, ${ }^{4}$ Department of Geosciences, Texas Tech University, Lubbock, TX. United States, ${ }^{5}$ Department of Earth and Atmospheric Sciences, University of Alberta, Edmonton, AB, Canada, ${ }^{6}$ Department of Geology, San Jose State University, San Jose, CA, United States, ' Department of Geological Sciences, San Diego State University, San Diego, CA, United States
}

Volcanic glasses are rarely preserved in the rock record, and the quality of preservation generally declines with increasing age. Records preserved in ancient basaltic glasses therefore provide important links between processes operating in the distant past, and those that are active on the Earth today. Microbial colonization has been linked to the formation of characteristic structures in basaltic glass, including tubules and granule-filled tubules, which are thought to be produced by microbially mediated glass dissolution. Structures of similar occurrence and morphology but filled almost entirely with fine-grained titanite have been documented in some ancient metabasalts. It has been suggested that the ancient titanite-mineralized structures are mineralized equivalents of hollow tubules in modern glassy basaltic rocks, but a direct link has not been firmly established. We report the discovery of tubular bioalteration structures in fresh and minimally altered basaltic glasses of middle Jurassic (164 Ma) age from the Stonyford Volcanic Complex (SFVC), Coast Range Ophiolite, California. Tubular structures hosted in unaltered basaltic glass are typically hollow, whilst those in zones of zeolitic alteration are mineralized by titanite. Tubules are continuous across zeolite-glass interfaces, which mark an abrupt change from titanite-filled to hollow tubules, demonstrating that titanite growth occurs preferentially within preexisting tubular structures. Titanite mineralization in the SFVC represent a link between tubular structures in modern basaltic glass and titanite-mineralized features of similar morphology and spatial distribution in ancient metabasalts. Our observations support a link between textures in modern glassy basaltic rocks and some of the oldest-known putative ichnofossils.

Keywords: ichnofossil, bioalteration, astrobiology, basaltic glass, titanite 


\section{INTRODUCTION}

The preservation of glass in ancient volcanic rocks is relatively rare, and occurs only where processes such as hydrothermal alteration, thermal metamorphism, and deformation were minimal or absent. In particular, the retardation of hydrothermal circulation by welding (to form massive glass) or cementation with calcite precipitated from seawater at low temperatures, appears to be critical to the preservation of ancient glass, as well as a tectonic setting that does not involve regional metamorphism and deformation. Thus, ancient volcanic glass is most commonly preserved in ophiolites and island arcs that are exposed by accretionary uplift of terranes formed in the upper plate of a subduction zone (e.g., Robinson et al., 1983; Shervais and Hanan, 1989; Shervais, 2001). Volcanic glass may also be preserved in oceanic settings prior to subduction, and may be sampled by drilling (Furnes et al., 1996; Fisk and McLoughlin, 2013).

Despite their rarity, ancient volcanic glasses provide important links between the past and processes that are active on the Earth today. They also preserve compositional and isotopic data documenting evidence of their magmatic and tectonic origins that may be lost during thermal or hydrothermal metamorphism. Most investigations of volcanic glass focus on the preservation of primary compositional and isotopic data (Robinson et al., 1983; Shervais and Hanan, 1989; Fisk and McLoughlin, 2013). In this paper, we present new evidence for microbial activity during the Jurassic that contributed to the alteration of basaltic glass in the SFVC (Shervais and Hanan, 1989), a remnant of the Coast Range ophiolite in northern California (Shervais et al., 2005a,b,c). The character of this activity is essentially identical to that of microbial alteration that is active today (Furnes et al., 1996; Fisk et al., 1998, 2003) and provides a link between currently observable/active processes and the past.

\section{Geological Context for the Stonyford Volcanic Complex}

The SFVC consists of sub-aqueous basalts, including both pillow lava and sheet flows, with intercalations of ribbon chert and hyaloclastite breccia (Shervais and Hanan, 1989; Shervais et al., 2005a,b). It is preserved as mega-blocks up to several $\mathrm{km}$ across in a serpentinite-matrix mélange that is continuous with ophiolite assemblages at Elder Creek, $35 \mathrm{~km}$ to the north (Hopson and Pessagno, 2005; Shervais et al., 2011). Plutonic rocks are not observed within the complex, but mélange blocks of wehrlite, gabbro, and diorite are common structurally below the complex (Shervais et al., 2004, 2005c). Volcanic rocks of the Stonyford complex comprise three suites: oceanic tholeiite, alkali basalt, and high-Al, low-Ti basalts. Each suite has distinct major and trace element characteristics that require derivation from different mantle source regions, but all three suites have isotopic compositions that require a subducted sediment component (Shervais et al., 2005c). Based on these data, and on the complete absence of any high-pressure metamorphic minerals, the complex has been interpreted to represent an oceanic seamount formed within the Coast Range ophiolite forearc in response to the collision of an active spreading center
(Shervais et al., 2004, 2005c). Previous interpretations correlating the SFVC with the Franciscan assemblage (Shervais and Kimbrough, 1985; Shervais and Hanan, 1989) were incorrect. Figure 1A shows the regional context of the SFVC, and Figure 1B shows a typical hyaloclastite outcrop sampled for the present study.

Hyaloclastite breccias composed of alkali basalt glass form layers that range from $\approx 1 \mathrm{~m}$ to almost $100 \mathrm{~m}$ thick, but more commonly 10-50 m thick, intercalated with pillow lava. The breccias consist largely of subangular to rounded lapilli of pale brown basaltic glass ( $\leq 3 \mathrm{~cm}$ across) in a matrix of glass shards $(\approx 0.1-1 \mathrm{~mm})$. The basaltic glass is microphyric

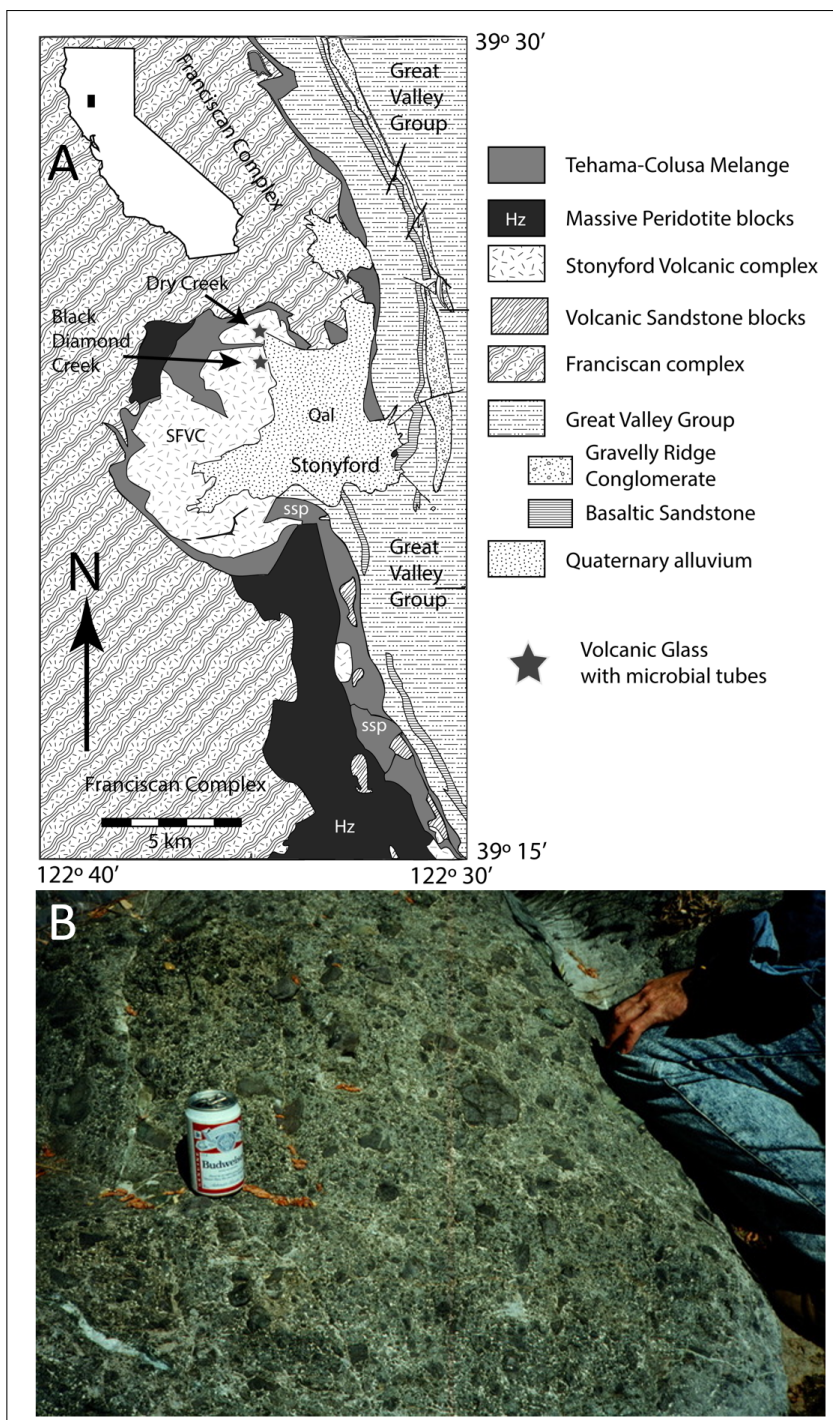

FIGURE 1 | (A) Map showing location of glass-rich horizons in the Stonyford Volcanic Complex (SFVC), which crop out in Dry Creek (glass samples G1-G4) and near Black Diamond Creek (glass samples G5, G8). The SFVC is separated from the high $\mathrm{P} / \mathrm{T}$ Franciscan complex by a serpentinite mélange (Shervais et al., 2011). Map adapted from Shervais et al. (2011). (B) Example of hyaloclastite (G3), showing outcrop-scale textures. Field hydration equipment for scale. 
with sparse microphenocrysts of olivine $\left(\mathrm{Fo}_{86-87}\right)$, plagioclase $\left(A n_{72}-80\right)$, and Cr-spinel (Shervais and Hanan, 1989). Bombs of crystalline basalt are common in some layers but absent in others. The breccias are cemented by calcite, analcime, three compositionally distinct generations of chlorite, and (rarely) heulandite. Cementation proceeded in several stages that included incipient replacement of some glass margins by interlayered smectite-chlorite, analcime, or heulandite (Shervais and Hanan, 1989). In addition, many of the glass lapilli are cut by hairline fractures that are lined with palagonite. The secondary assemblage was interpreted by Shervais and Hanan (1989) to represent maximum temperatures of $\sim 100^{\circ} \mathrm{C}$, based on the presence of analcime and the absence of laumontite.

Major and trace element analyses of the glass show that it is alkali basalt with $\mathrm{K}_{2} \mathrm{O} \approx 0.6-0.9 \mathrm{wt} \%$ and LREE-enriched patterns (chondrite-normalized), similar to other alkali basalts in the volcanic complex (Shervais and Hanan, 1989; Shervais et al., 2005c). ${ }^{40} \mathrm{Ar} /{ }^{39} \mathrm{Ar}$ dates for hand-picked glass lapilli by Paul Renne (Shervais et al., 2005a) cluster around $164.5 \pm 0.5 \mathrm{Ma}$ or Bathonian on the Jurassic time scale of Palfy et al. (2000). These dates are supported by detailed radiolaria biostratigraphy, analyzed by Benita Murchey and reported in Shervais et al. (2005a), which shows that the intercalated chert horizons range in age from Bajocian or Bathonian at the base of the complex to Oxfordian near the top $(\approx 166-155 \mathrm{Ma}$ on the Jurassic timescale of Palfy et al. (2000). These ages are significantly older than those estimated previously (Tithonian, $\approx 150 \mathrm{Ma}$ ) based on poorly preserved radiolarian assemblages in hydrothermally altered chert (Pessagno, 1977).

\section{MATERIALS AND METHODS}

Thin sections of SFVC hyaloclastite glass were examined in transmitted light using a Nikon Eclipse LV100 POL petrographic microscope equipped with a Nikon DS-Ri1 12 Mpixel camera. Scanning Electron Microscopy (SEM) and Energy-Dispersive $\mathrm{X}$-ray spectroscopy (EDS) was carried out using a Hitachi S-4300SE/N field emission SEM with Genesis EDAX EDS spectrometer at College of Arts \& Sciences Microscopy, Texas Tech University, using an electron-beam accelerated to between 10 and $20 \mathrm{kV}$ and a $13 \mathrm{~mm}$ working distance, with a $1 \mu \mathrm{m}$ beam diameter. Additional SEM observations were performed on a JEOL JSM-6301FXV instrument at the University of Alberta connected to a Princeton Gamma Tech IMIX energydispersive spectrometer system. The analyses were performed at an accelerating voltage of $20 \mathrm{kV}$ and a working distance of $15 \mathrm{~mm}$. Selected regions were also analyzed using a FE-SEM JEOL JSM-7001F field emission source scanning electron microscope at the Institute for Planetary Materials, Okayama University, with $5 \mathrm{nA}$ beam current and $15 \mathrm{kV}$ acceleration voltage at a working distance of $10 \mathrm{~mm}$ and $1 \mu \mathrm{m}$ beam diameter.

$\mathrm{X}$-ray element mapping and compositional analysis, including for light elements $(\mathrm{C}, \mathrm{N})$ were carried out with a JEOL JXA8900R electron probe micro-analyzer (EPMA) at the University of Alberta using an accelerating voltage of $15 \mathrm{kV}$ and probe current of $3.0 \times 10^{-8} \mathrm{~A}$ and a $5 \mu \mathrm{m}$ beam diameter. Carbon and nitrogen peaks were calibrated using silicon carbide and boron nitride, respectively, and because carbon was an element of interest, thin sections were coated with a thin film of iridium measuring approximately $40 \AA$ thick (Banerjee and Muehlenbachs, 2003). To monitor reproducibility and improve counting statistics carbon was routinely measured on two spectrometers. Instrument calibration for EPMA of elements other than $\mathrm{C}$ and $\mathrm{N}$ were performed on natural and synthetic standard materials. Additional wavelength-dispersive analysis was conducted using a JEOL JXA-8800R EPMA at the Institute for Planetary Materials, Okayama University with accelerating voltage $15 \mathrm{kV}$ and a probe current of $1.2 \times 10^{-8} \mathrm{~A}$ with a $5 \mu \mathrm{m}$ beam diameter.

Micro X-ray diffraction ( $\mu$ XRD) measurements were carried out using a Bruker D8 Discover microdiffractometer with a Co source (Co $\mathrm{K} \alpha, \lambda=1.7902 \AA$ ) operating at $35 \mathrm{kV}$ and $40 \mathrm{~mA}$. Monocapillary optics and a $300 \mu \mathrm{m}$ snout were used to create a collimated beam of $300 \mu \mathrm{m}$ diameter. Diffracted $\mathrm{X}$-rays were detected with a two-dimensional General Area Detector Diffraction System (GADDS). Scans were collected in "coupled" scan mode, with fixed source and detector (Flemming, 2007). Integrated diffractograms were interpreted using the International Center for Diffraction Data (ICDD) Powder Diffraction File ver. 4 (ICDD PDF-4) database.

Hand-picked glass particles were cleaned of external carbonate cement, so that the analyzed carbonate is interpreted to be primarily internal to the tubule-bearing glass assemblage. Stable carbon isotope analyses were performed by pouring $100 \%$ phosphoric acid on powders under vacuum (McCrea, 1950) and analyzing the evolved $\mathrm{CO}_{2}$ using a Finnigan MAT 252 mass spectrometer at the University of Alberta. The data are reported in the usual delta-notation with respect to Vienna Pee Dee Belemnite (VPDB) (Craig, 1957; Coplen, 1994). Yields of $\mathrm{CO}_{2}$ in the samples varied from 0.03 to $6 \%$ by weight. The precision of the carbon isotope analysis is $\pm 0.03 \%$.

\section{RESULTS}

\section{Microtubules in Fresh Glass}

Glass preservation at Stonyford is excellent, as can be seen in Figure 2. Apart from localized zones of alteration along fractures, the basaltic glass shards are clear, pale brown in color, and optically isotropic. They do not diffract X-rays and display the characteristic "glass hump" in X-ray scans, confirming that they have been preserved in an amorphous state. Electron-probe micro-analyses of the fresh glass have totals that range from 97 to $99.7 \%$, indicating that hydration is minimal (Table $\mathbf{1}$ ).

Tubules within glassy areas are abundant along many fracture surfaces (FS) and often form closely spaced arrays of densely packed tubules (Figure 2). Tubules originate from fracture surfaces or shard boundaries, and propagate inward, roughly perpendicular to the originating surface (Figure 2). Similar to modern seafloor microtubules (Staudigel et al., 2015), most SFVC features within glass are 1-2 $\mu \mathrm{m}$ in diameter and range up to $\sim 200-300 \mu \mathrm{m}$ in length. The tubules are mostly hollow and typically form smooth curves, but complex 


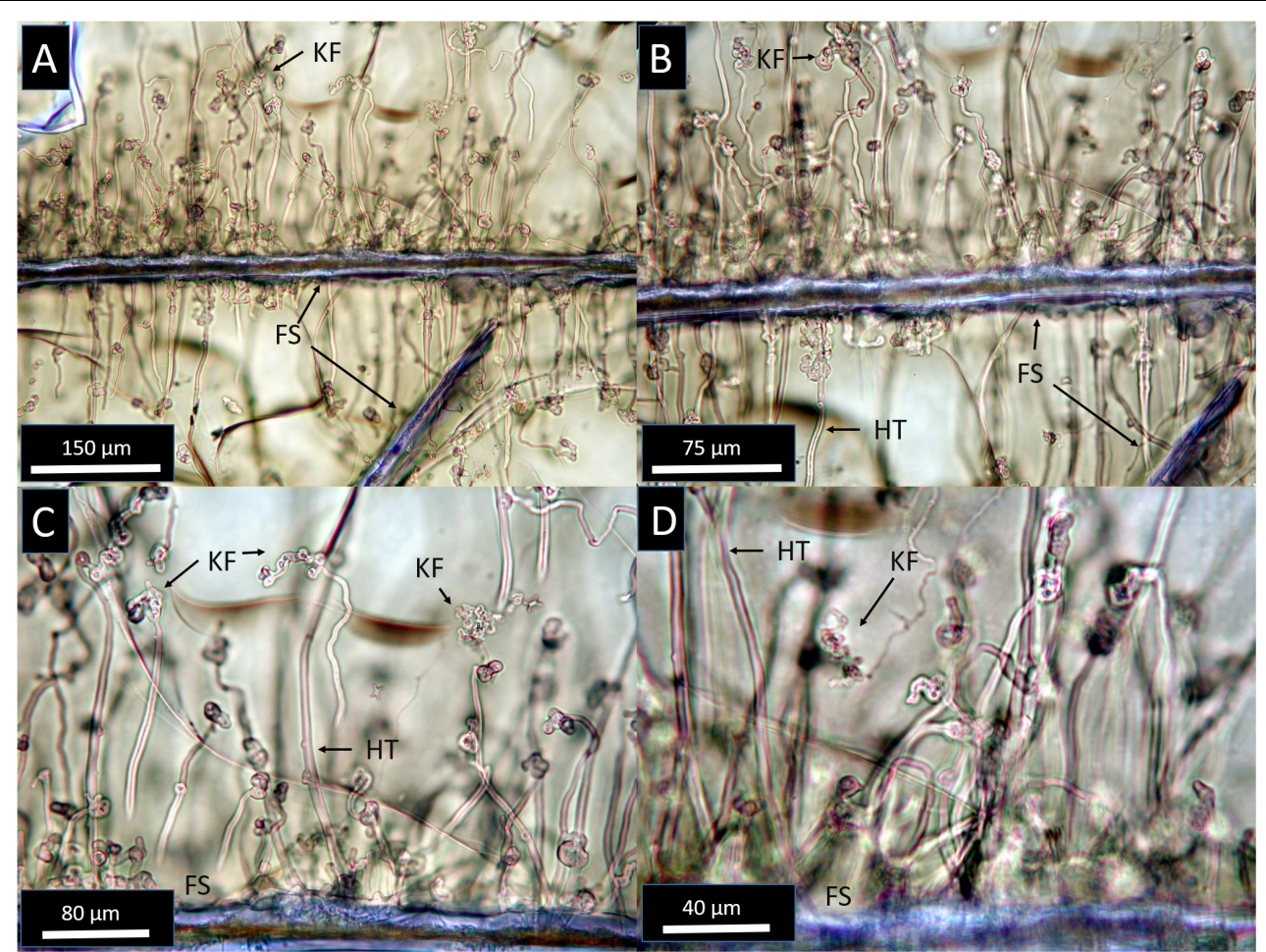

FIGURE 2 | Transmitted light photomicrographs at increasing magnification from (A-D), showing the diversity of primary microtubule textures in Stonyford glasses. Tubules are rooted along exposed fracture surfaces (FS) and propagate into unaltered glass (pale brown). Most SFVC tubules are hollow and smooth-walled (HT), and many show complex knotted forms especially near their endpoints (KF).

TABLE 1 | Quantitative analysis of SFVC minerals and glass by EPMA

\begin{tabular}{|c|c|c|c|c|c|c|c|c|c|c|}
\hline $\mathrm{SiO}_{2}(\mathrm{wt} \%)$ & $\mathrm{TiO}_{2}(\mathrm{wt} \%)$ & $\mathrm{Al}_{2} \mathrm{O}_{3}(\mathrm{wt} \%)$ & $\mathrm{Cr}_{2} \mathrm{O}_{3}(\mathrm{wt} \%)$ & $\mathrm{FeO}(w \mathrm{t} \%)$ & $\mathrm{MnO}(w \mathrm{t} \%)$ & $\mathrm{MgO}(\mathrm{wt} \%)$ & $\mathrm{CaO}(w \mathrm{t} \%)$ & $\mathrm{Na}_{2} \mathrm{O}(w t \%)$ & $\mathrm{K}_{2} \mathrm{O}(\mathrm{wt} \%)$ & Total \\
\hline \multicolumn{11}{|c|}{ Basaltic glass } \\
\hline 50.50 & 1.89 & 17.43 & 0.07 & 8.24 & 0.00 & 7.74 & 10.70 & 1.17 & 0.77 & 98.50 \\
\hline 50.56 & 1.90 & 17.73 & 0.02 & 8.43 & 0.00 & 7.88 & 10.55 & 0.93 & 0.75 & 98.75 \\
\hline 50.19 & 1.86 & 17.75 & 0.08 & 8.17 & 0.03 & 7.66 & 9.93 & 0.72 & 0.70 & 97.08 \\
\hline \multicolumn{11}{|c|}{ Titanite (mixed analysis with zeolite) } \\
\hline 36.67 & 21.19 & 7.63 & 0.19 & 1.92 & 0.00 & 0.23 & 24.91 & 0.08 & 0.06 & 92.87 \\
\hline 31.63 & 19.39 & 6.89 & 0.20 & 1.58 & 0.02 & 0.51 & 27.62 & 0.12 & 0.05 & 88.01 \\
\hline 43.98 & 16.08 & 11.92 & 0.17 & 1.43 & 0.02 & 0.67 & 18.57 & 0.13 & 0.06 & 93.04 \\
\hline 33.60 & 20.47 & 7.18 & 0.18 & 1.87 & 0.00 & 0.56 & 26.46 & 0.11 & 0.06 & 90.51 \\
\hline \multicolumn{11}{|l|}{ Zeolites } \\
\hline 55.01 & 0.01 & 16.26 & 0.00 & 0.03 & 0.00 & 0.53 & 7.65 & 0.56 & 0.04 & 80.09 \\
\hline 54.80 & 0.11 & 16.14 & 0.00 & 0.17 & 0.01 & 0.56 & 7.91 & 0.42 & 0.04 & 80.17 \\
\hline 56.62 & 0.00 & 16.80 & 0.00 & 0.08 & 0.00 & 0.51 & 7.79 & 0.30 & 0.02 & 82.12 \\
\hline 59.32 & 0.00 & 18.26 & 0.00 & 0.03 & 0.00 & 0.47 & 8.34 & 0.12 & 0.07 & 86.63 \\
\hline 60.10 & 0.00 & 16.80 & 0.00 & 0.08 & 0.00 & 0.20 & 8.30 & 0.01 & 0.00 & 85.48 \\
\hline
\end{tabular}

knotted tangles are common, especially toward the ends of the tubules (Figure 2). The tubules do not display internal striae or segmentation, though some rare cases show small projections or buds from tubule walls. Bifurcation or branching of SFVC tubules is exceedingly rare, and in common with tubular textures from in situ oceanic crust localities, SFVC tubules have not been observed to cross one another, which may be related to microbial feeding behavior (Walton, 2008;
McLoughlin et al., 2009). Tubules commonly terminate in rounded or complex, knotted forms, but terminal mineral inclusions have not been observed.

\section{Microtubules in Altered Glass}

Some regions of basaltic glass have been replaced with a colorless assemblage of Ca-rich zeolites (Figure 3), identified by $\mu \mathrm{XRD}$ as analcime, Ca-phillipsite, Ca-stilbite, and rarely, 


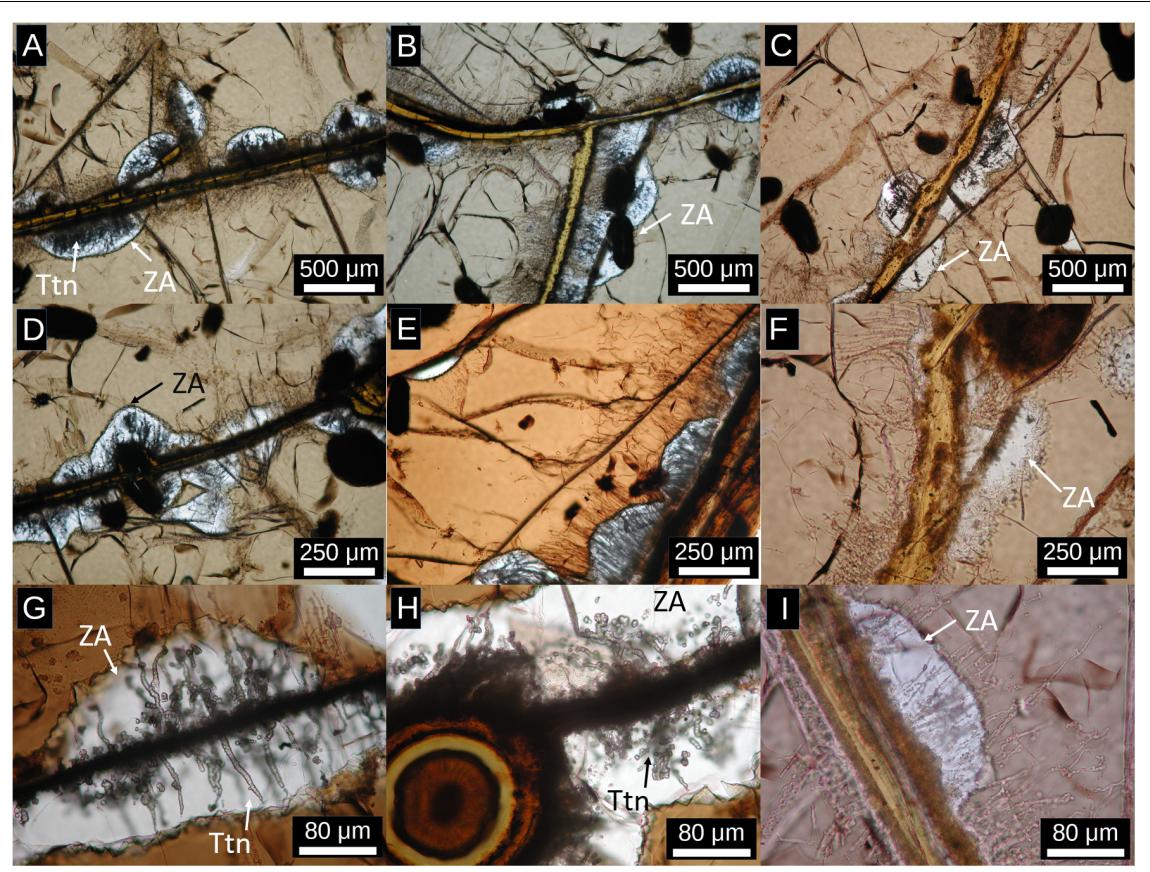

FIGURE 3 | Transmitted light photomicrographs at a variety of scales showing tubules within regions of zeolitic alteration (white, ZA). (A-C) 20× magnification, (D-F) $40 \times$ magnification, (G-I) $80 \times$ magnification. Primary tubules within glass are mostly hollow, while within the zeolitic alteration, they are overprinted by fine-grained titanite (high relief, gray-white, Ttn). Zeolite alteration typically nucleates along fracture surfaces and expands into the glass (pale brown), forming smoothly curved interfaces with glass. Zeolite alteration is commonly, but not exclusively, centered on regions with high tube densities, suggesting that high tube densities enhance fluid access to the glass. Also visible are regions of palagonite variably stained by Fe-oxyhydroxides, such as the concentric rounded object in panel (H).

tschernichite (Figure 4). These patches of zeolitic alteration are localized along shard boundaries and fractures, and commonly display crystal forms at the interface between glass and zeolite. Tubule morphology typically changes within the zones of zeolite mineralization: while tubules in the fresh glass are smooth (Figure 3), those in the zeolite alteration zones commonly display a granular texture with a rough surface appearance (Figure 3). Within these zeolite zones, tubules are mineralized by fine-grained titanite. Tubules are continuous between zeolite and glass, with the parts of tubules lying within the zeolite alteration zones mineralized by fine-grained titanite and those within glass mostly hollow (Figure 5). Correlated optical and backscattered electron imaging further illustrating the textural relationship between zeolite alteration assemblages hosting titanite-mineralized tubules and the surrounding basaltic glass with hollow primary tubules are shown in Figure 6.

\section{Geochemical Signatures of the Microtubules}

Compositional microanalysis using backscattered electron imaging and EDS compositional maps (Figure 7) indicates that the tubule-filling materials within zeolitic alteration zones are composed of $\mathrm{Ca}, \mathrm{Ti}, \mathrm{Si}$, and $\mathrm{O}$ with trace $\mathrm{Fe}$, and that the host material is composed dominantly of $\mathrm{Ca}, \mathrm{Al}, \mathrm{Si}$, and $\mathrm{O}$, consistent with titanite in a calcian zeolite host. The surrounding unaltered basaltic glass shows X-ray lines for $\mathrm{Si}, \mathrm{Na}, \mathrm{Al}, \mathrm{Mg}, \mathrm{Ca}$, $\mathrm{Fe}$, consistent with a basaltic composition. Elemental mapping of glass-hosted open tubules with wavelength-dispersive spectroscopy reveals that biologically important elements including $\mathrm{C}, \mathrm{N}$, and $\mathrm{P}$ are associated with tubular structures, both in the unaltered basaltic glass and within the zeolite alteration zones (Figure 8). Carbon stable isotope data fall mostly between mantle and seawater values (Figure 9). Carbon and oxygen stable isotopic compositions and total $\mathrm{CO}_{2}$ yield are summarized in Table 2.

\section{DISCUSSION}

\section{Origin and Preservation of Tubules in the SFVC Samples}

Microscopic hollow tubules and granular structures in subaqueous basaltic glass have been reported from numerous localities worldwide (e.g., Staudigel et al., 2008a; Fisk and McLoughlin, 2013). Microbes are hypothesized to promote the dissolution of basaltic glass to liberate nutrients through energy-yielding redox reactions, or as components of biomolecules, through reactions such as (Emerson and Moyer, 2002):

$$
\begin{array}{r}
4 \mathrm{Fe}^{2+}+10 \mathrm{H}_{2} \mathrm{O}+\mathrm{O}_{2}=4 \mathrm{Fe}(\mathrm{OH})_{3}+8 \mathrm{H}^{+} \\
{[108 \mathrm{~kJ} / \mathrm{molFe}]}
\end{array}
$$

Other nutrients that could be obtained through leaching of basaltic glass include other transition metals, phosphorous, 


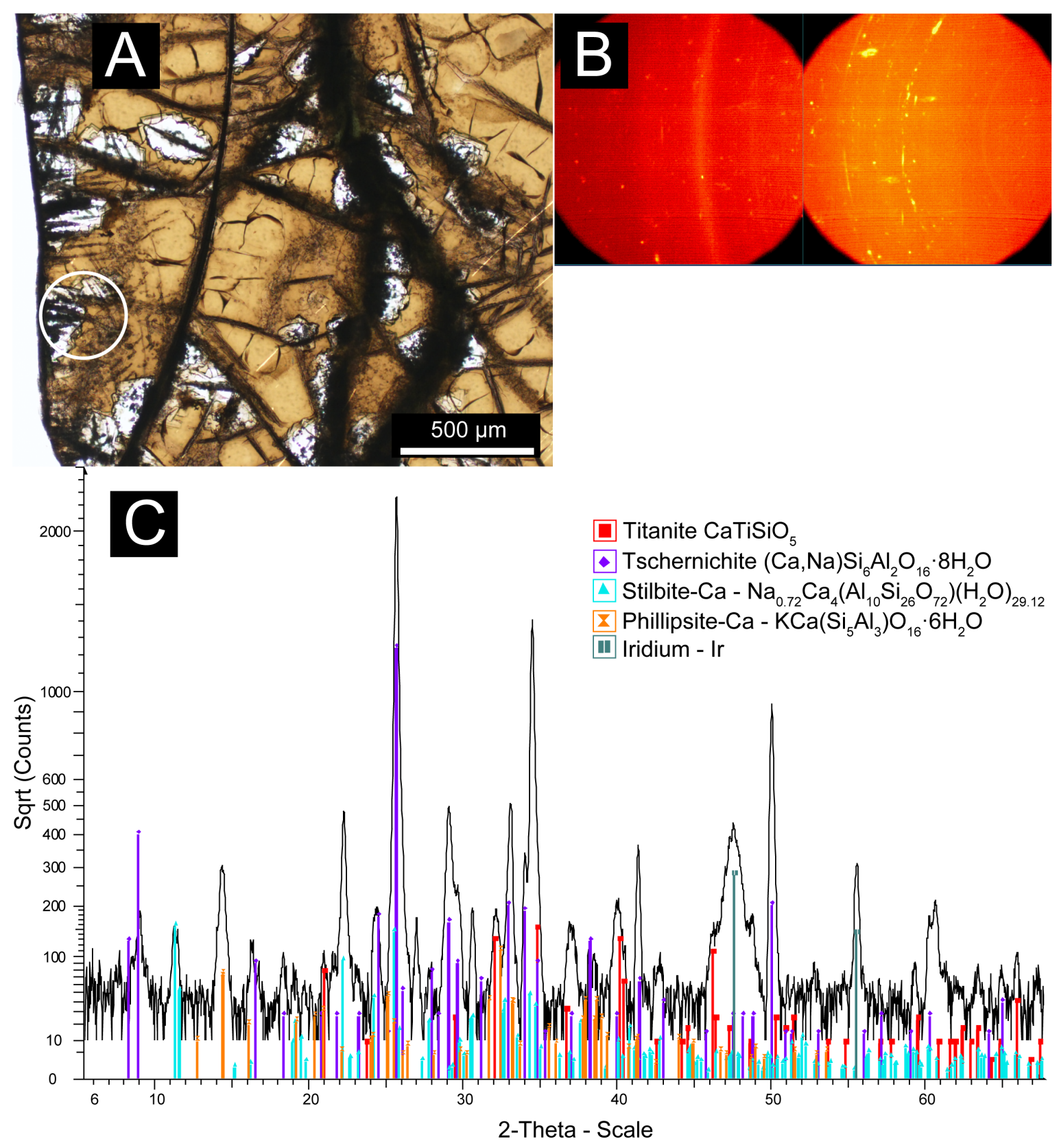

FIGURE 4 | Micro XRD data showing the mineralogy of the zeolite alteration zone hosting titanite-mineralized tubules. (A) Transmitted plane-polarized light (PPL) photomicrograph with the nominal $300 \mu \mathrm{m}$ beam in area analyzed footprint marked by the white circle. (B) General Area Detector Diffraction System (GADDS) images showing distribution of diffracted X-ray intensity. Discontinuous "spotty" Debye rings correspond to zeolites, whilst continuous rings correspond to fine-grained titanite and the iridium layer deposited for electron beam analysis. (C) Integrated, background-subtracted diffractogram with International Center for Diffraction Data (ICDD) pattern matches to: tschernichite (Ca, Na) $\mathrm{Si}_{6} \mathrm{Al}_{2} \mathrm{O}_{16} \cdot 8 \mathrm{H}_{2} \mathrm{O}(046-1396)$, Titanite $\mathrm{CaTiSiO}_{5}(050-1614), \mathrm{Stilbite} \mathrm{Ca} \mathrm{Na}_{0} \cdot{ }_{2} \mathrm{Ca}_{4}\left(\mathrm{Al}_{10} \mathrm{Si}_{26} \mathrm{O}_{72}\right)$ $\left(\mathrm{H}_{2} \mathrm{O}\right)_{29 \cdot 12}(079-1676)$, Phillipsite- $\mathrm{Ca}-\mathrm{KCa}\left(\mathrm{Si}_{5} \mathrm{Al}_{3}\right) \mathrm{O}_{16} \cdot 6 \mathrm{H}_{2} \mathrm{O}(039-1375)$, iridium coating (006-0598).

and potassium. It is worthy of note that the SFVC glasses have higher $\mathrm{K}$ concentrations than most seafloor basaltic glasses and the increased $\mathrm{K}$ concentrations may have made the SFVC glasses more amenable to microbial colonization and growth than typical low-K oceanic tholeiites (Shervais and Hanan, 1989; Shervais et al., 2005c). High alkali concentrations may also enhance glass dissolution by depolymerization of the silicate network (Mysen and Frantz, 1993). Another possible mechanism of formation in response to a natural proton flux from seawater into the glass generated during glass alteration as protons from water replace cations in the glass (Fisk et al., 2019).

Tubular structures highly reminiscent of those in seafloor basaltic glasses have been documented in (rare) basaltic glass preserved in ophiolites, and in metamorphosed pillow rims in 


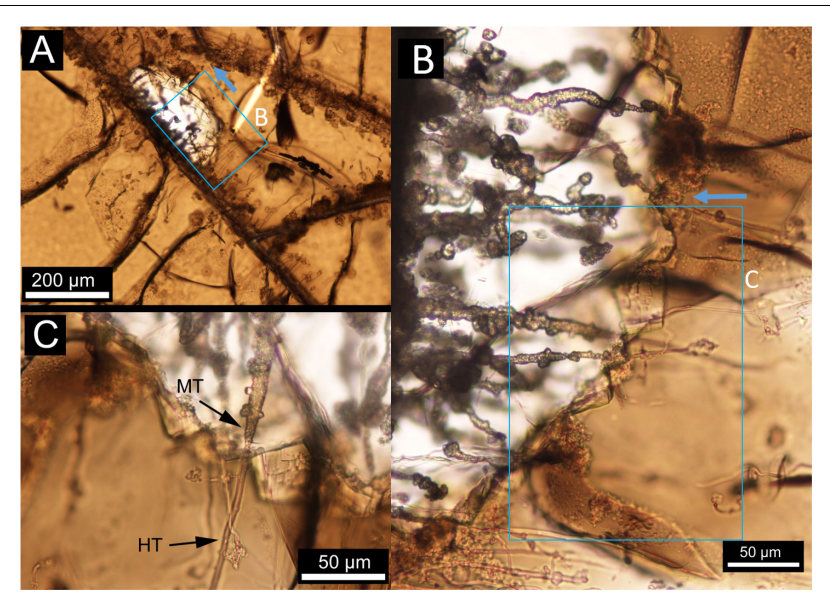

FIGURE 5 | Transmitted, plane-polarized-light photomicrographs of altered basaltic glasses hosting partially mineralized tubular alteration textures. (A) Large-scale view showing the formation of tubular textures rooted along fracture surfaces and extending into the basaltic glass, approximately perpendicular to the originating fracture surface. The panels $(\mathbf{B}, \mathbf{C})$ detail showing the transition from zeolite alteration zones (colorless) to fresh glass (brown). Note that tubular textures are continuous between the two zones; however, the parts of tubules lying within the zeolite alteration zones have been mineralized by titanite (MT), whereas the tubules are mostly hollow within unaltered glass $(\mathrm{HT})$. Boxes with arrows denote the location and up direction of the succeeding image.

ophiolites and greenstone belts (Furnes et al., 2005; Banerjee et al., 2006; Staudigel et al., 2008a; Wacey et al., 2014). In metabasaltic rocks, these tubular features are commonly dominated by finegrained titanite (Furnes et al., 2005; Staudigel et al., 2008a). Morphological evidence for a biogenic origin for tubular textures in basaltic includes segmented, bifurcated and spiral/helical tubule forms (Furnes et al., 2007; Staudigel et al., 2008b; Walton, 2008; McLoughlin et al., 2009). Putative bioalteration structures in the SFVC samples are always rooted on surfaces that were formerly exposed to external water, and were not observed completely enclosed in glass (Figure 2). Tubules located on conjugate sides of cracks are not aligned (Figure 2), as would be expected if the tubules formed as a result of dissolution along pre-existing weaknesses in the glass (Furnes et al., 2001; Staudigel et al., 2008a). In most instances, glass replacement is focused on zones with high tubule densities, suggesting that the tubules may enhance local alteration of the glass (Figure 3). The occurrence and textural characteristics of SFVC tubules are similar to those of many other putative microbial ichnofossils (e.g., Staudigel et al., 2008a; Fisk and McLoughlin, 2013). If interpreted as ichnofossils following the taxonomy of McLoughlin et al. (2009), the SFVC tubules are most consistent with the Tubulohyalichnus simplus ichnofossil taxon.

Elements of potential biological importance, including C, $\mathrm{N}$, and $\mathrm{P}$ show elevated concentrations associated with tubular alteration in the SFVC tubules (Figure 8), similar to putative microbial bioalteration textures documented in other subaqueous basaltic glasses (e.g., Banerjee and Muehlenbachs, 2003; Banerjee et al., 2011). In this study, the presence of

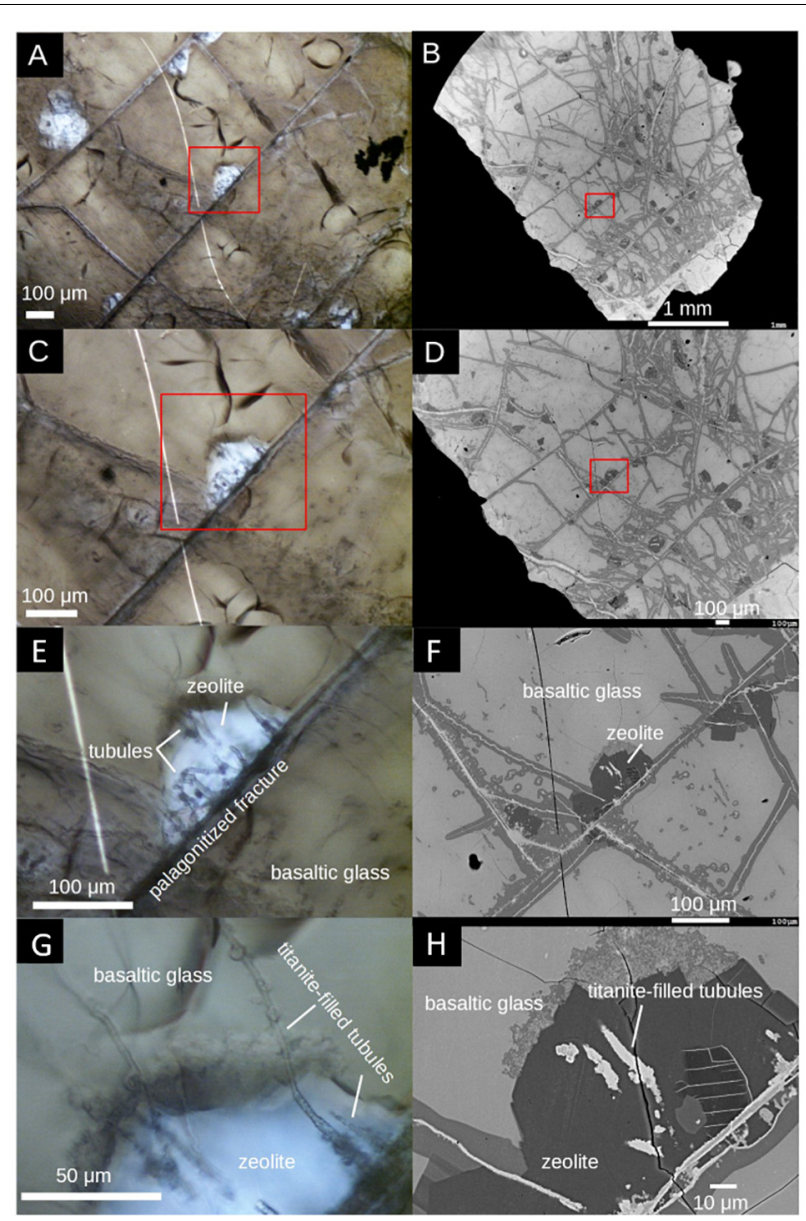

FIGURE 6 | Correlated optical (left column) and SEM backscattered electron (right column) imagery of a representative mineralized tubule location at various scales. (A-D) Zeolite-titanite assemblages occur along cracks and fractures that pervade the hyaloclastite glass. (E,F) Tubules are rooted on fracture surfaces. $\mathbf{( G , H ) ~ T u b u l e s ~ w i t h i n ~ z e o l i t e s ~ a r e ~ m i n e r a l i z e d ~ b y ~ t i t a n i t e , ~ i n ~}$ contrast, tubules within basaltic glass are mainly hollow.

organic materials may be indicated by the elevated levels of $\mathrm{C}$ and $\mathrm{N}$ associated with tubules (Figure 8). Organic compounds, including aliphatic, aromatic, carboxylic, and amide moieties have been directly detected within tubules in fresh basaltic glass (Preston et al., 2011). Staining with compounds that target nucleic acids indicate that biological material is concentrated at the interface between the fresh and altered glass and especially in the walls and tips of tubular structures (Furnes et al., 1996; Giovannoni et al., 1996; Banerjee and Muehlenbachs, 2003). It is also possible that some of the carbonaceous material detected by EPMA includes finegrained carbonates, similar to carbonates detected within tubules in seafloor basaltic glass (Benzerara et al., 2007). The $\delta^{13} C$ values of carbonate extracted from SFVC glass samples mainly show evidence of interaction between seawater and basalt, but one sample does contain light carbon of uncertain origin (Figure 9). Banerjee and Muehlenbachs (2003) showed that the carbonate carbon isotope compositions of pillow basalt 


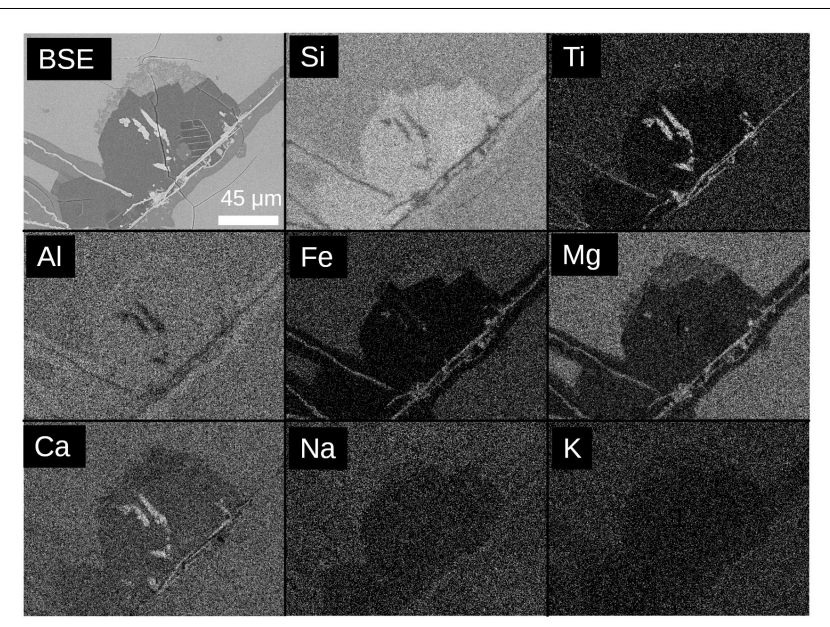

FIGURE 7 | Compositional microanalysis of a representative region including backscattered electron (BSE) and energy-dispersive X-ray spectrometry (indicated elements, $\mathrm{K}$-alpha lines). Titanite-mineralized tubules exposed on the section surface are visible as $\mathrm{Ca}$ - and Ti-rich regions within the zeolitic host (Si-rich, Fe-poor), and surrounded by basaltic glass (Mg- and- Fe-rich, lower Si than zeolite). Scale bar identical in each image. Scale identical in each image. Optical and additional BSE images of this region are also shown in Figure 6 .

cores and glassy tubule-bearing hyaloclastite rims are consistent with the incorporation of biologically fractionated carbon, with the rims having consistently low $\delta^{13} C$ values compared to the interiors.
The data presented here demonstrate that tubular structures may be preserved or pseudomorphed by titanite mineralization. While not every tubule is titanite-pseudomorphed, but the phenomenon is ubiquitous enough to provide a very plausible fossilization mechanism. In the SFVC samples, the fact that titanite mineralization is localized within the sections of tubular microtunnels that have been converted to zeolites, while it is largely absent from tubules in unaltered glass, supports the proposal that tubular structures are preserved or fossilized by titanite-mineralization. It has been suggested that the passive accumulation of $\mathrm{Ti}$ during microbial glass dissolution may provide nuclei for later titanite growth (Furnes et al., 2005; Knowles et al., 2013). The observation of titanite in little-altered basaltic glass from the OntongJava Plateau (Izawa et al., 2010a,b), and of Ti-rich particles within the unaltered glass in this study (Figure 10), are consistent with a passive accumulation mechanism. This study provides direct evidence for localization of titanite mineralization within tubular microtunnels in metamorphosed basaltic glass. Staudigel et al. (2014, 2015) proposed a twostage model where passive accumulation mechanism preconcentrates $\mathrm{Ti}$ within tubular structures, prior to largescale titanite growth during metamorphism. Observations from the SFVC samples reported here support the two stage model, with titanite-mineralized tubules concentrated in zeolitized, metamorphosed zones with some small $\mathrm{Ti}$ rich particles within the mainly hollow tubules in unaltered zones of SFVC glass, "ahead" of the titanite-zeolite alteration front (Figure 10).

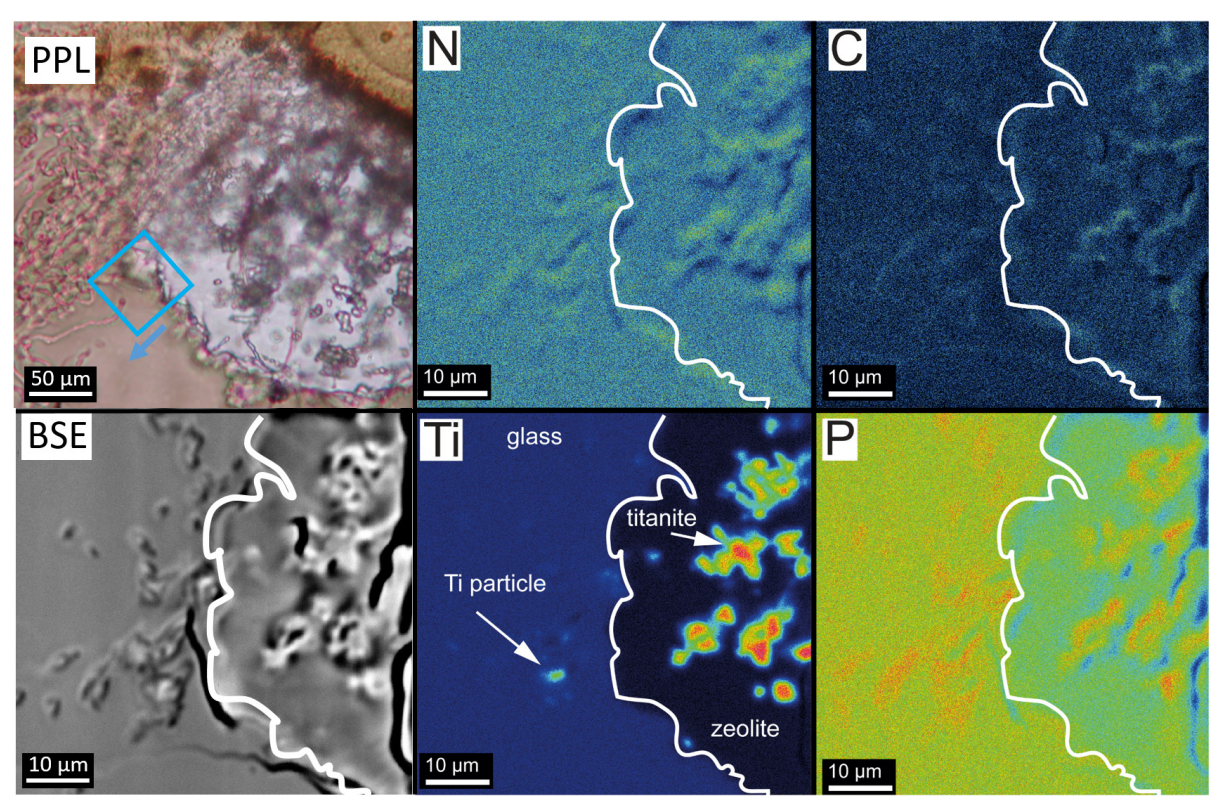

FIGURE 8 | Electron microprobe energy-dispersive X-ray maps of a representative area at the interface between unaltered basaltic glass and the zeolite alteration. The biologically important elements N, C, and P are associated with tubular textures in both unaltered basaltic glass, and Ti-rich titanite within the zeolite-mineralized zone. Isolated Ti-rich objects within the unaltered material (e.g., the small object marked by the white arrow in the Ti map) may represent early formed precursors to metamorphic titanite. A plane-polarized light (PPL) context image and backscattered electron (BSE) image are included for context, arrow indicates the up direction in the EPMA and BSE images. 


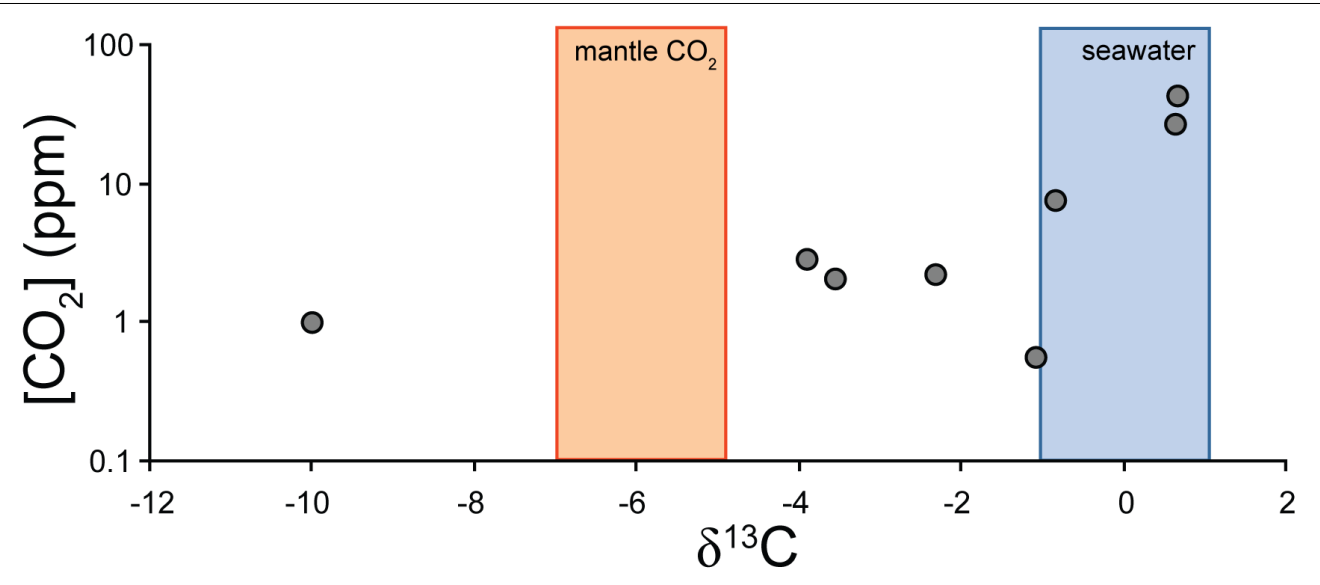

FIGURE 9 | Carbonate stable carbon isotope and $\mathrm{CO}_{2}$ yield data for SFVC separates, with ranges for the mantle and seawater marked by colored bars. All but one of the data fall between mantle and seawater, consistent with carbonate derived largely from these sources. The anomalous sample, G9, contains additional light carbon of uncertain origin.

\section{Implications for Putative Archæan Ichnofossils}

A longstanding debate has surrounded the interpretation of titanite features within metamorphosed basaltic glasses as a record of microbial activity. Grosch and McLoughlin (2014) have called into question the link between microbial ichnofossils in modern basaltic glasses (Fisk et al., 1998; Banerjee and Muehlenbachs, 2003; McLoughlin et al., 2009) and titanite microtextures documented in metabasalts (Furnes et al., 2004; Staudigel et al., 2015), suggesting instead a purely metamorphic origin for the titanite microtextures. While the results of the present study do not demonstrate that all titanite microtextures are derived from pre-existing microbial ichnofossils, the SFVC samples do convincingly show that such hollow features can be mineralized by titanite. Therefore, we conclude that titanite mineralization of microbial ichnofossils is a plausible mechanism for the formation of titanite microtextures in ancient metabasalts.

Partially mineralized tubules from the SFVC firmly link microtubules in seafloor basaltic glass with titanitemineralized tubules in ancient metabasalts. This study documented the transition from largely hollow tubules in fresh, unaltered basaltic glass (formed by microbial mining

TABLE 2 | Carbon and oxygen isotopic compositions for SFVC glass samples.

\begin{tabular}{lllll}
\hline Sample ID & d13C & d180 & P c02 & Weight (g) \\
\hline SFV-G3 & 0.671 & 29.949 & 41.71 & 1.1389 \\
SFV-G3 & 0.657 & 30.154 & 25.84 & 0.5052 \\
SFV-G9 & -9.974 & 21.074 & 0.96 & 0.8856 \\
SFV-G2 BAS & -0.827 & 26.944 & 7.35 & 0.7333 \\
SFV-G2 GL & -3.533 & 25.027 & 2.01 & 0.7213 \\
SFV-G7 & -1.062 & 24.481 & 0.54 & 0.7579 \\
SFV-G4 & -2.301 & 26.89 & 2.2 & 0.7504 \\
SFV-G5 & -3.879 & 10.095 & 2.82 & 0.7696
\end{tabular}

of the glass for energy) to titanite-mineralized tubules and pseudo-tubules in altered or metamorphosed basaltic glass. If these features are the mineralized equivalents of microbial structures found in modern seafloor basaltic glass, they constitute an ichnofossil record of microbial activity in volcanic rocks dating back to Archæan times, possibly as far as $\sim 3.5 \mathrm{Ga}$ (Banerjee et al., 2007; Fliegel et al., 2010).

It has been suggested that many titanite tubules in metabasalts are the result of dendritic crystal growth during metamorphism and therefore constitute pseudofossils, i.e., abiogenic structures that mimic fossils (Lepot et al., 2011). An important observation in the SFVC samples is that hollow tubules are contiguous with titanite-mineralized tubules, commonly changing abruptly at the interface between basaltic glass and a zeolite-rich alteration assemblage (Figures 3, 5). Terminal mineral inclusions and striated interior surfaces would be expected if the tubular features were ambient inclusion trails. The hollow sections of tubules within glass do not contain terminal mineral inclusions nor do they have striated interior surfaces. Our observations instead support an origin of titanite-mineralized tubules as ichnofossils produced by the mineralization of initially hollow microbial etch structures. Titanite has previously been observed in association with bioaltered basaltic glass, showing that titanite formation begins early in the alteration history of basaltic glass (Izawa et al., 2010a,b). It is possible that microbially mediated glass dissolution leads to the passive accumulation of $\mathrm{Ti}$ providing one of the necessary constituents for titanite and other Ti-bearing phases (Banerjee and Muehlenbachs, 2003; Knowles et al., 2013). During later metamorphism, these titanite-bearing precursor materials provide a template for overgrowths of metamorphic titanite. This is consistent with the observations reported here: titanite growth is localized in tubular bioalteration textures. Because the tubules are filled with fine-grained titanite, the original biogenic morphologies are well-preserved. 


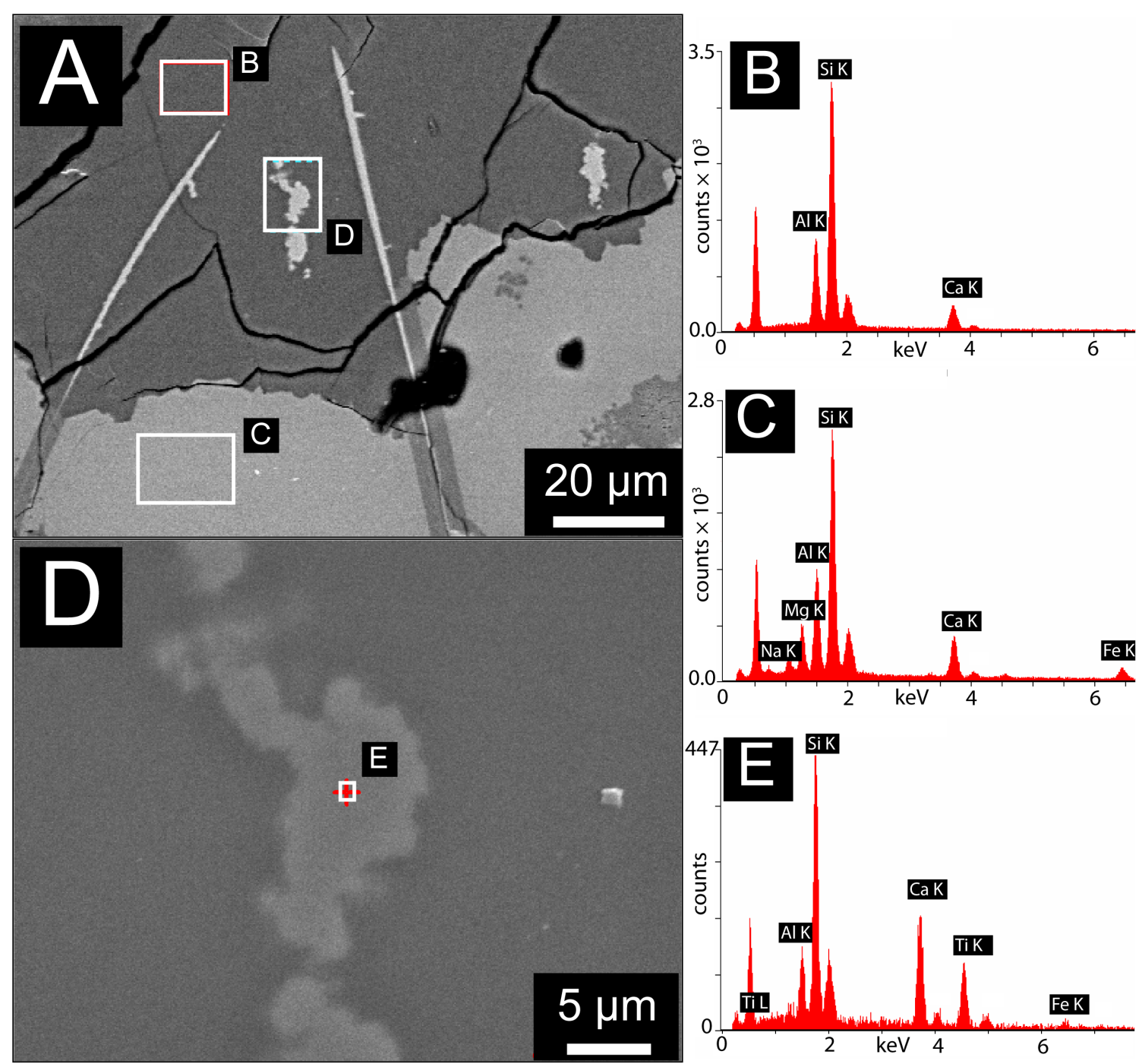

FIGURE 10 | Scanning Electron Microscopy with Energy Dispersive X-ray Spectroscopy (SEM-EDX) results for a representative region containing both unaltered basaltic glass and zeolite alteration containing titanite-mineralized tubules. (A) SEM Back Scattered Electron (BSE) image showing zeolitic alteration (dark gray) containing titanite-mineralized tubules (visible here as bright areas exposed at the surface of the zeolite host, e.g., area labeled "D"). Also visible are unalted basaltic glass (light gray) and isolated linear features filled with fine-grained Fe-oxyhydroxides (bright linear features cross-cutting between glass and zeolite). (B) EDX spectrum of the area marked by the corresponding box in (A), showing the presence of $\mathrm{Al}, \mathrm{Si}$, and $\mathrm{Ca}$, consistent with the calcian zeolite alteration assemblage. (C) EDX spectrum of the area marked by the corresponding box in (A), showing the composition of unaltered basaltic glass. (D) High magnification image of a titanite-mineralized tubule exposed at the surface of the thin section, this region is marked by the corresponding box in (A). (E) EDX spectrum of the point marked by the cross in (A), showing elevated concentrations of $\mathrm{Ca}$ and $\mathrm{Ti}$, consistent with titanite and in accord with $\mu$ XRD diffractograms and optical images showing the presence of titanite in these areas.

\section{CONCLUSION}

The investigation of partially titanite-mineralized tubules within SFVC basaltic glasses has provided several new insights.

(1) Tubules meeting the textural and geological context criteria for microbial ichnofossils occur throughout SFVC basaltic glasses and are most consistent with the Tubulohyalichnus simplus ichnofossil taxon (McLoughlin et al., 2009).
(2) Titanite mineralization in candidate microbial ichnofossils is localized within zeolite-rich alteration and commonly located along fractures and cracks within basaltic glass. Titanite mineralization follows along pre-existing hollow tubules in the SFVC glasses, with titanite-mineralized regions within zeolite merging with open tubules at the glass-alteration zone interface.

(3) Micron-scale Ti-rich particles occur scattered within the hollow tubule zones, consistent with titanite mineralization occurring preferentially within tubules due to accumulation of $\mathrm{Ti}$ within the tubules, possibly as a 
result of passive accumulation during microbial etching. These findings reinforce previous detections of titanite associated with tubules from other locations (Izawa et al., 2010a).

(4) The SFVC samples demonstrate that preservation of candidate microbial ichnofossils by titanite mineralization has occurred at least in this case, and supports the interpretation of some titanite microtextures in metabasalts as bona fide microbial trace fossils.

Microbial ichnofossils consisting of hollow tubules in basaltic glass have been observed at a stage representing the transformation from hollow tubules to titanite-filled tubular structures. The titanite-filled structures are interpreted as an early stage in the formation of titanite-filled tubular features like those documented in many ancient metabasalts including some of Archæan age. The SFVC glasses investigated here clearly demonstrate the possibility of a direct link between tubular microbial ichnofossils in modern seafloor basaltic glasses and titanite-mineralized structures in Archæan metabasalts, supporting previous interpretations of the Archæan features as a record of microbial activity in basaltic rocks stretching back to at least $3.5 \mathrm{Ga}$. This in turn supports the view that a microbial habitat based at least in part on basaltic glass as a substrate has been present on Earth for most of recorded geologic time, and that a record of this biological activity can be preserved in metabasalts, even through significant metamorphism.

\section{AUTHOR CONTRIBUTIONS}

MI carried out the optical petrography, micro-XRD, EPMA, and SEM analysis, analyzed the data, and wrote the manuscript. NB collected the petrographic, EPMA, and isotopic data, and wrote

\section{REFERENCES}

Banerjee, N., Furnes, H., Muehlenbachs, K., Staudigel, H., and de Wit, M. (2006). Preservation of 3.4-3.5 Ga microbial biomarkers in pillow lavas and hyaloclastites from the Barberton Greenstone Belt, South Africa. Earth Planet. Sci. Lett. 241, 707-722. doi: 10.1016/j.epsl.2005.11.011

Banerjee, N., Izawa, M., Sapers, H., and Whitehouse, M. (2011). Geochemical biosignatures preserved in microbially altered basaltic glass. Surf. Interf. Anal. 43, 452-457. doi: 10.1002/sia.3577

Banerjee, N., and Muehlenbachs, K. (2003). Tuff life: bioalteration in volcaniclastic rocks from the Ontong Java Plateau. Geochem. Geophys. Geosyst. 4, 1037-1059. doi: 10.1029/2002GC000470

Banerjee, N. R., Simonetti, A., Furnes, H., Muehlenbachs, K., Staudigel, H., Heaman, L., et al. (2007). Direct dating of Archean microbial ichnofossils. Geology 35, 487-490.

Benzerara, K., Menguy, N., Banerjee, N. R., Tyliszczak, T., Brown, G. E. Jr., and Guyot, F. (2007). Alteration of submarine basaltic glass from the Ontong Java Plateau: a STXM and TEM study. Earth Planet. Sci. Lett. 260, 187-200. doi: 10.1016/j.epsl.2007.05.029

Coplen, T. (1994). Reporting of stable hydrogen, carbon, and oxygen isotopic abundances. Pure Appl. Chem. 66, 273-276. doi: 10.1351/pac199466020273

Craig, H. (1957). Isotopic standards for carbon and oxygen and correction factors for mass-spectrometric analysis of carbon dioxide. Geochim. Cosmochim. Acta 12, 133-149. doi: 10.1016/0016-7037(57)90024-8

Emerson, D., and Moyer, C. (2002). Neutrophilic Fe-oxidizing bacteria are abundant at the Loihi seamount hydrothermal vents and play a major role in $\mathrm{Fe}$ the manuscript. RF contributed the expertise on micro-XRD and mineralogy. $\mathrm{CH}$ carried out the SEM analysis and optical petrography. KM aided in the interpretation of the isotopic data and involved in the project design. JS, CS, and BH collected the samples and provided the field and petrographic context. DD conducted the optical and SEM imaging and EPMA. All authors assisted in the data analysis and interpretation, and contributed to the writing of the manuscript.

\section{FUNDING}

MI gratefully acknowledges the support from the Natural Sciences and Engineering Research Council of Canada (NSERC), IODP Canada, the Canadian Astrobiology Training Program (CATp), and the Mineralogical Association of Canada. NB and RF received funding from NSERC. This work was supported by a Research Council of Norway Post-Doctoral Fellowship to NB and grants from the National Science Foundation (JS and $\mathrm{BH}$ ) and Natural Sciences and Engineering Research Council of Canada (KM).

\section{ACKNOWLEDGMENTS}

The authors thank S. Matveev for the help with the X-ray mapping, O. Levner for the help with the stable isotope analyses, M. Grimson for the technical assistance with the SEM at Texas Tech University, and G. Braybrook for the help with the SEM at the University of Alberta. The authors also thank reviewers Huan Cui and Gerhard Franz for thorough and constructive criticism that led to substantial improvements, and Mónica Sánchez-Román for editorial service (and great patience).

oxide deposition. Appl. Environ. Microbiol. 68, 3085-3093. doi: 10.1128/aem. 68.6.3085-3093.2002

Fisk, M., Giovannoni, S., and Thorseth, I. (1998). Alteration of oceanic volcanic glass: textural evidence of microbial activity. Science 281, 978-980. doi: 10.1126/ science. 281.5379 .978

Fisk, M., and McLoughlin, N. (2013). Atlas of alteration textures in volcanic glass from the ocean basins. Geosphere 9, 317-341. doi: 10.1130/ges00827.1

Fisk, M., Storrie-Lombardi, M. C., Douglas, S., Popa, R., McDonald, G., and Di Meo-Savoie, C. (2003). Evidence of biological activity in Hawaiian subsurface basalts. Geochem. Geophys. Geosyst. 4, 1103-1127. doi: 10.1029/2002gc0 00387

Fisk, M. R., Popa, R., and Wacey, D. (2019). Tunnel formation in basalt glass. Astrobiology 19, 132-144. doi: 10.1089/ast.2017.1791

Flemming, R. (2007). Micro X-ray diffraction mu XRD): a versatile technique for characterization of earth and planetary materials. Can. J. Earth Sci. 44, 1333-1346. doi: 10.1139/e07-020

Fliegel, D., Kosler, J., McLoughlin, N., Simonetti, A., de Wit, M. J., Wirth, R., et al. (2010). In-situ dating of the Earth's oldest trace fossil at $3.34 \mathrm{Ga}$. Earth Planet. Sci. Lett. 299, 290-298. doi: 10.1016/j.epsl.2010.09.008

Furnes, H., Banerjee, N., Muehlenbachs, K., and Kontinen, A. (2005). Preservation of biosignatures in metaglassy volcanic rocks from the Jormua ophiolite complex, Finland. Precambrian Res. 136, 125-137. doi: 10.1016/j.precamres. 2004.09.009

Furnes, H., Banerjee, N., Muehlenbachs, K., Staudigel, H., and de Wit, M. (2004). Early life recorded in archean pillow lavas. Science 304, 578-581. doi: 10.1126/ science. 1095858 
Furnes, H., Banerjee, N. R., Staudigel, H., Muehlenbachs, K., McLoughlin, N., Wit, M., et al. (2007). Comparing petrographic signatures of bioalteration in recent to Mesoarchean pillow lavas: tracing subsurface life in oceanic igneous rocks. Precambrian Res. 158, 156-176. doi: 10.1016/j.precamres.2007. 04.012

Furnes, H., Staudigel, H., Thorseth, I. H., Torsvik, T., Muehlenbachs, K., and Tumyr, O. (2001). Bioalteration of basaltic glass in the oceanic crust. Geochem. Geophys. Geosyst. 2:1049.

Furnes, H., Thorseth, I. H., Tumyr, O., Torsvik, T., and Fisk, M. R. (1996). Microbial Activity in the Alteration of Glass From Pillow Lavas From HOLE 896A. College Station, TX: Texas A \& M University.

Giovannoni, S. J., Fisk, M. R., and Furnes, H. (1996). Genetic evidence for endolithic microbial life colonizing basaltic glass/sea water interfaces. Proc. Ocean Drill. Prog. 148, 207-214.

Grosch, E., and McLoughlin, N. (2014). Reassessing the biogenicity of Earth's oldest trace fossil with implications for biosignatures in the search for early life. Proc. Natl. Acad. Sci. U.S.A. 111, 8380-8385. doi: 10.1073/pnas.14025 65111

Hopson, C., and Pessagno, E. (2005). Tehama-Colusa serpentinite melange: a remnant of Franciscan jurassic oceanic lithosphere, northern California. Int. Geol. Rev. 47, 65-100. doi: 10.2747/0020-6814.47.1.65

Izawa, M., Banerjee, N., Flemming, R., and Bridge, N. (2010a). Preservation of microbial ichnofossils in basaltic glass by titanite mineralization. Can. Mineral. 48, 1255-1265. doi: 10.3749/canmin.48.5.1255

Izawa, M., Banerjee, N., Flemming, R., Bridge, N., and Schultz, C. (2010b). Basaltic glass as a habitat for microbial life: implications for astrobiology and planetary exploration. Planet. Space Sci. 58, 583-591. doi: 10.1016/j.pss.2009.09.014

Knowles, E., Staudigel, H., and Templeton, A. (2013). Geochemical characterization of tubular alteration features in subseafloor basalt glass. Earth Planet. Sci. Lett. 374, 239-250. doi: 10.1016/j.epsl.2013.05.012

Lepot, K., Benzerara, K., and Philppot, P. (2011). Biogenic versus metamorphic origins of diverse microtubes in $2.7 \mathrm{Gyr}$ old volcanic ashes: multi-scale observations. Earth Planet. Sci. Lett. 312, 37-47. doi: 10.1016/j.epsl.2011.10.016

McCrea, J. (1950). On the isotopic chemistry of carbonates and a paleotemperature scale. J. Chem. Phys. 18, 849-857. doi: 10.1063/1.1747785

McLoughlin, N., Furnes, H., Banerjee, N., Muehlenbachs, K., and Staudigel, H. (2009). Ichnotaxonomy of microbial trace fossils in volcanic glass. J. Geol. Soc. 166, 159-169. doi: 10.1144/0016-76492008-049

Mysen, B. O., and Frantz, J. D. (1993). Structure and properties of alkali silicate melts at magmatictemperatures. Eur. J. Mineral. 3, 393-408. doi: 10.1038/ s41598-017-16741-3

Palfy, J., Smith, P., and Mortensen, J. (2000). A U-Pb and Ar-40/Ar-39 time scale for the Jurassic. Can. J. Earth Sci. 37, 923-944. doi: 10.1073/pnas.1009828109

Pessagno, E. A. Jr. (1977). Upper Jurassic Radiolaria and radiolarian biostratigraphy of the California Coast Ranges. Micropaleontology 23, 56-113.

Preston, L., Izawa, M., and Banerjee, N. (2011). Infrared spectroscopic characterization of organic matter associated with microbial bioalteration textures in basaltic glass. Astrobiology 11, 585-599. doi: 10.1089/ast.2010.0604

Robinson, P., Melson, W., O’Hearn, T., and Schminke, H. (1983). Volcanic glass compositions of the Troodos ophiolite, Cyprus. Geology 11, 400-404.

Shervais, J. (2001). Birth, death, and resurrection: the life cycle of suprasubduction zone ophiolites. Geochem. Geophys. Geosyst. 2:200GC000080.

Shervais, J., Choi, S. H., Sharp, W. D., Ross, J., Zoglman-Schuman, M., and Mukasa, S. B. (2011). Serpentinite matrix mélange: implications of mixed provenance for mélange formation. Geol. Soc. Am. Spec. Pap. 480, 1-38.
Shervais, J., and Hanan, B. (1989). Jurassic volcanic glass from the stonyford volcanic complex, franciscan assemblage, Northern California coast ranges. Geology 17, 510-514.

Shervais, J., and Kimbrough, D. (1985). Geochemical evidence for the tectonic setting of the coast range ophiolite - A composite island arc-oceanic crust terrane in Western California. Geology 13, 35-38.

Shervais, J., Kimbrough, D. L., Renne, P., Hanan, B. B., Murchey, B., Snow, C. A., et al. (2004). Multi-stage origin of the Coast Range ophiolite, California: implications for the life cycle of supra-subduction zone ophiolites. Int. Geol. Rev. 46, 289-315. doi: 10.2747/0020-6814.46.4.289

Shervais, J., Murchey, B., Kimbrough, D., Renne, P., and Hanan, B. (2005a). Radioisotopic and biostratigraphic age relations in the Coast Range Ophiolite, northern California: implications for the tectonic evolution of the Western Cordillera. Geol. Soc. Am. Bull. 117, 633-653.

Shervais, J., Kolesar, P., and Andreasen, K. (2005b). A field and chemical study of serpentinization - Stonyford, California: chemical flux and mass balance. Int. Geol. Rev. 47, 1-23. doi: 10.2747/0020-6814. 47.1.1

Shervais, J., Schuman, M., and Hanan, B. (2005c). The Stonyford volcanic complex: a forearc seamount in the northern California Coast Ranges. J. Petrol. 46, 2091-2128. doi: 10.1093/petrology/egi048

Staudigel, H., Furnes, H., and De Wit, M. (2015). Paleoarchean trace fossils in altered volcanic glass. Proc. Natl. Acad. Sci. U.S.A. 112, 6892-6897. doi: 10.1073/ pnas. 1421052112

Staudigel, H., Furnes, H., McLoughlin, N., Banerjee, N. R., Connell, L. B., Templeton, A., et al. (2008a). 3.5 billion years of glass bioalteration: volcanic rocks as a basis for microbial life? Earth Sci. Rev. 89, 156-176. doi: 10.1016/j.earscirev.2008.04.005

Staudigel, H., Furnes, H., Mcloughlin, N., Banerjee, N., Connell, L. B., and Templeton, A. (2008b). Microbial glass bioalteration: inferring mechanisnis of blocorrosion from trace fossil morphology. Geochim. Cosmochim. Acta 72, A893-A893.

Staudigel, H., Furnes, H., and Smits, M. (2014). Deep biosphere record of in situ oceanic lithosphere and ophiolites. Elements 10, 121-126. doi: 10.2113/ gselements.10.2.121

Wacey, D., McLoughlin, N., Saunders, M., and Kong, C. (2014). The nano-scale anatomy of a complex carbon-lined microtube in volcanic glass from the similar to 92 Ma Troodos Ophiolite, Cyprus. Chem. Geol. 363, 1-12. doi: 10.1016/j. chemgeo.2013.10.028

Walton, A. (2008). Microtubules in basalt glass from Hawaii scientific driling project \#2 phase 1 core and Hilina slope, Hawaii: evidence of the occurrence and behavior of endolithic microorganisms. Geobiology 6, 351-364. doi: 10 . $1111 /$ j.1472-4669.2008.00149.x

Conflict of Interest: The authors declare that the research was conducted in the absence of any commercial or financial relationships that could be construed as a potential conflict of interest.

Copyright (C) 2019 Izawa, Banerjee, Shervais, Flemming, Hetherington, Muehlenbachs, Schultz, Das and Hanan. This is an open-access article distributed under the terms of the Creative Commons Attribution License (CC BY). The use, distribution or reproduction in other forums is permitted, provided the original author(s) and the copyright owner(s) are credited and that the original publication in this journal is cited, in accordance with accepted academic practice. No use, distribution or reproduction is permitted which does not comply with these terms. 